\title{
Rethinking the Boundary Between Human and Nonhuman: Jeanette Winterson's The stone gods as a Transgression Experiment
}

\author{
Zhang Jin ${ }^{1,2}$, Wang Weiwei ${ }^{3}$ \\ ${ }^{1}$ Center for Foreign Literature and Culture, Guangdong University of Foreign Studies, Guangzhou, China \\ ${ }^{2}$ Institute of Advanced Studies, University of Chinese Academy of Social Sciences, Beijing, China \\ ${ }^{3}$ School of Foreign Studies, Guangdong University of Finance \& Economics, Guangzhou, China
}

Email address:

1192700435@qq.com (Zhang Jin),2427474011@qq.com (Wang Weiwei)

To cite this article:

Zhang Jin, Wang Weiwei. Rethinking the Boundary Between Human and Nonhuman: Jeanette Winterson's The stone gods as a Transgression Experiment. International Journal of Literature and Arts. Special Issue: Humanity and Science: China's Intercultural Communication with the Outside World in the New Era. Vol. 8, No. 2, 2020, pp. 33-38. doi: 10.11648/j.ijla.20200802.11

Received: February 27, 2020; Accepted: March 11, 2020; Published: March 31, 2020

\begin{abstract}
As a world-famous writer, Jeanette Winterson, as well as her novels, have been well-known for her lesbian theme and love theme. Little attention has been paid to the theme of transgression. However, studies have shown that transgression experiment is also the key theme through all of the novels by Jeanette Winterson. In the Stone Gods, she still keeps this narrative style and gives an attempt to stir the people to re-evaluate the boundary between human and nonhuman, attracting much more attention to the issues of transgression experiment and the result after transgression. In this paper, based on the Jenks' theory of transgression, we found out that there are two ways that (1) broadening the definition of body;(2) breaking the boundary between human and environment, which could be accepted to attempt to explore the issues of boundary between human and nonhuman to examine whether the boundary could be crossed in The Stone Gods. In these ways, it is found out that the real aim when Winterson regards the novel as a transgression experiment is to not merely break a rule, rebel against normative social and cultural constraints, but rather lead a dynamic trend in cultural production and diverse discourse, in order to stimulate readers to have dynamic thought about everything.
\end{abstract}

Keywords: Jeanette Winterson, The stone gods, Transgression Experiment, Human and Nonhuman

\section{Introduction}

Jeanette Winterson is a famous female writer, and one of the most controversial and innovative novelists in Britain. She is enjoying a high international reputation, whose works include novels, poems, comics, children literature, literary reviews and tele scripts and so on. Winterson has won a number of awards at home and abroad. She was named as one of "the 20 Best of Young British Writers" coined by the famous literary magazine Grant and BBC 100 Women. Winterson's novels are full of her own characteristics, and are systematically with the themes of transgression experiment and of great artistic value. Those novels all involve good connection on the research of the issues of boundaries, which should be studied as a system.

It is mentioned in previous part that Winterson's works are, to certain degree, under the influence of the transgressive thought, which could be summarized as two reasons.

First, Winterson has been deeply affected by her family and religion. Winterson was born in Manchester and brought up by her adoptive parents, in a strict Pentecostal Evangelist faith. Her adoptive father was a worker in a television factory and her mother was a housewife. "As a Northern, low-church working-class girl she was expected to do militant religious work, to accept compulsory heterosexuality and to avoid developing her intellectual and artistic capacities" [1]. When she spent her childhood and youth devising cunning ways to fight against the religious rules and principles, as well as her mother 's ban on reading and all kinds of ridiculous demands, Winterson was also affected, and explored an array of ways of crossing those boundaries and formed a series of transgressive thought.

Second, Winterson has also been influenced by the social 
rules and environment at that time. She was born in 1959 and grew up in the near mill-town of Accrington, Lancashire. After the fifties of the $20^{\text {th }}$ century, Britain had faced a systematically threat to their economic position as well as to their survival in the world, while the life of the British had been under great influence. Therefore, the British started to search for changes in many perspectives, including the literary circle. What is more, posthumanist ontologies of the material body foregrounded by various figures from both the natural and social sciences, moved the postmodern discussions of the discursive body in a new direction, resulting in the emergence of a posthuman turn. This new focus on the materiality of the body also triggered a shift in the contemporary British novel, which is evident in Jeanette Winterson's later work, such as her 2007 novel, The Stone Gods [2].

Therefore, we find out that Winterson forms the thought about the issues of boundary with her characteristics under the influence of collective factors. She regards crossing the boundaries as a transgressive experiment in her novel, in which she attempts to stimulate readers to pay closer attention to the issues of boundaries and the conduct of transgression in our society. In all of Winterson's novels, it is found that the issue of transgression experiment is taken as an important theme throughout all her works.

\section{Literature Review}

When measured by the quality of journal articles, The Stone Gods has attracted some attention from readers and critics from home and abroad. Accordingly, much studies on The Stone Gods have attempted to examine this book from the perspective of love, homo-sexuality and so on. In addition, there is also some information about research on the environmentalism about struggling with the perceived chasm between nature and culture, or the human and the nonhuman in Jeanette Winterson's The Stone Gods [3]. In spite of some insightful studies such as analyzing the dystopian apocalyptic vision of human civilization in the novel by Michaela Weiss [4], study about how to question the idea of normative history and take space as the physical environment distributed among various groups by seeing the identity as unstable entity [5], analysis of boundary and desire from the perspective of Philosophical Nomadism [6], and a critical posthumanist reading of Jeanette Winterson's The Stone Gods through re-materializing postmodernism, and drawing on material ecocriticism and on the concept of "narrative agency" [7], there is little information available in literature about the issues of boundary between human and non-human, as well as regarding the works as an experiment of transgression.

Recently, Winterson's study and criticism has witnessing a wide turn from lesbian, autobiography, love, to her language, narrative style and postmodern thought. Besides, Winterson's works also speak out for the poor, the animal, and the same-sex lovers, the margin group, so does The Stone Gods. This book keeps and follows the writing style of Winterson, focusing on the silenced and the oppressed. She not only takes the transgressive experiment, pointing out devastating cultural and ecological consequences, but also pushes readers to think the issues of boundaries. Because Jeanette Winterson claimed in an interview before that she hoped her novels would motivate the readers think. Therefore, she attempts to content questions in novels in order to unravel its purpose and meaning. In this book, it is consistently found that she gives significant attention to questioning constructions of human/non-human, as well as exploring the issues of boundary between human and non-human.

Therefore, in this paper, this study aims to analyzes Winterson's novel, The Stone Gods, systematically concentrating on transgressing the boundaries between human and non-human, by resorting to British history, culture and social background, in order to explore the issues of boundaries and analyze those social problems, nature and meanings which are raised by these issues.

\section{Methodology}

This study applies the theory of transgression by Chris Jenks, a British sociologist, to critically analyze the boundary between human and non-human in The Stone Gods by Jeanette Winterson. What resides in the word 'transgression'? According to Chris Jenks, "to transgress is to go beyond the bounds or limits set by a commandment or law or convention, it is to violate or infringe"[8]. This is also common concept about transgression, which is adopted by many literature critics. Besides, Jenks added that "But to transgress is also more than this, it is to announce and even laudate the commandment, the law or the convention. Transgression is a deeply reflexive act of denial and affirmation. Analytically, then, transgression serves as an extremely sensitive vector in assessing the scope, direction and compass of any social theory, as we shall see" [8]. Jenks' concept of transgression captures the central elements in Winterson's novels. In this sense, transgression is defined as behaviors or conducts that break principles or rules, or cross boundaries, which is a key feature of postmodern thought. In addition, transgression services as a deeply reflexive act of denial and exceeding the boundaries as well. This thought is wildly received by postmodern thinkers, and literary and cultural critics, Winterson who is accepted, and is systematically used in her novels.

\section{The Boundary Between Human and Non-human}

Jeanette Winterson's The Stone Gods is chosen to be the analytical text. In this paper, we will attempt to offer a reading of The Stone Gods as focusing on the perspective of transgression experiments, which is framed by postmodern thought of science fiction.

Winterson's The Stone Gods could be summarized as follows: the content of this novel could be divided into four parts; the first part talks about the life in Orbus, which is a planet very like the earth, where has run out of resources and 
suffered from the severe effects of climate change. In that world, everybody likes enhancing by bio-technology, and feels bored. It is written that this is a world where has out of possibilities at all. Luckily, a new planet, Planet Blue, is discovered, which is perfect for human life, but there is only one defect-dinosaurs. Before sending all human to the new planet, the guide Billie Crusoe, a disillusioned scientist in Parts 1, 3, 4, and a young sailor, (Billy), in Part 2, and Spike, a perfect robo-sapiens, who undertakes a missionary work that have to get rid of the dinosaurs.

Previous research found that Winterson likes to regard the novel, the literary world, as a transgression experiment to examine whether the boundary could be crossed, and analyzes the results that when the boundary be transgressed. Actually, the central concern for Winterson in the transgression experiment is not merely crossing the boundaries, but also leading a dynamic trend in cultural production and diverse discourse, both of which form the fundamental and important philosophical basis for Winterson's entire oeuvre. Therefore, the purpose of this study is to focus on exploring the boundary between human and nonhuman, and push readers to move out the comfort zone and think deeply in The Stone Gods in two ways.

\subsection{Broadening the Definition of Body}

Body narrative plays a key role in the novels by Winterson, despite of her representation of love, expression of liberty, and transgression of boundary. This style of narrative was kept in narrative style in the novels of The Stone Gods, by which Winterson aims to examine the issue of boundary between human and nonhuman.

The Stone Gods, as a science fiction, is vivid illustration of critical postmodern thought and dehumanization of mankind. In this book, Winterson attempts to discuss the definition of human body. In the era of renaissance, human was be regarded as the divine and had divine right that distinguished from other species, so as human body. There is a definite boundary between human body and others, which could not be questioned from then on. This boundary, as well as other social boundaries, has been accepted by people and still been kept in human's mind. And nobody gives an attempt to question them. Under the influence of collective factors, including grown-up experiences and social environment, Winterson attempts to blur the boundary between human body and nonhuman body in two ways in this novel.

First, Winterson points out that human body not merely includes the organic part. With the development of technology and biology, the definition of human body is broadened. In Planet Blue of this book, Winterson describes that the human body not just includes the organic body, but the inorganic part. They can change the body by biology and technology. They also could change their ages and outlooks by fixing their DNA. In this planet, age is information failure, people could change their body parts by fixing their DNA and other bio-technology. They call that they are in the "DNA Dynasty", because "the body is designed to repair and renew itself, and most cells are only about a third as old as our years." [9]. Men and women could change their outlook as they like. Although this experience is a little overstate, it does not mean that it could not become true. Actually, nowadays there are many familiar cases in our society, such as face lifting, allotransplantation, and so on. This is also called cyborg, which is quoted from Donna Haraway’s “A Cyborg Manifesto: Science, Technology, and Socialist-Feminism in the Late Twentieth Century" [10], which was defined by Haraway as emphasizing "the confusion of boundaries". It is also noted by Barnett that "Donna Haraway, the radical feminist historian of science who argues that we are all cyborgs because our bodies are mediated by technology, perpetrated this infiltration initially" [11]. From the case above, it is found that human body not only includes organic body, rather is a composition of embodied nonhuman and human matter, including organic and inorganic matter, which is called "cyborg". In the meantime, organic allotransplantation will prove and be a new breakthrough of crossing the boundary between human and non-human. Therefore, Winterson gives an attempt to push readers to question those traditional boundaries positively and bravely.

Although Winterson likes to cross the boundaries, in this case, she does not blind worship transgressing the boundaries, rather arise readers to pay more attention to think deeply the issues of boundary by transgression experiment. She implies that the transgression of boundaries is not the result she aims to, but the act that attempts to generate readers' desires to extend the limits and think twice. What she really aims to do is to make us question whether we still feel definitely sure what we believed in before. Just as Jenks' book on transgression argues,

"Transgressive behavior therefore does not deny limits or boundaries, rather it exceeds them and thus completes them. Every rule, limit, boundary or edge carries with it its own fracture, penetration or impulse to disobey. The transgression is a component of the rule. Seen in this way, excess is not an abhorration nor a luxury, it is rather a dynamic force in cultural reproduction - it prevents stagnation by breaking the rule and it ensures stability by reaffirming the rule" [8].

In the Planet Blue of this book, when women need to stop her husband fall in love with young girl, she would try to refresh herself genetically, in order to look younger and more youthful. From the dialogue of the heroine Billie, it shows those women's desire and expectation obviously, "I have an appointment today with a woman who wants to be genetically reversed to twelve years old to stop her husband running after schoolgirls." [9]. This is just a satire narrative, which aims to ask human not to rely on technology completely. As Antakyalığlu claims that, "Plastic surgery, DNA modification and genetic age fixing are widespread, and no longer optional. The system prohibits natural ageing and becomes a hell of sameness". [12]. Winterson had mentioned that she also felt ambivalent when facing this problem in an interview,

"I am ambivalent, because I think that the real problems of the human condition won't be solved by another set of gadgets or even by spectacular interventions of the DNA kind. I introduce the idea of "genetic fixing" in The Stone Gods, with 
people choosing their ages. But when we're all young and beautiful and everything's supposed to work, it's still going to be a nightmare because the problems are inside our heads. They aren't going to go away just because we all look like star gods. Even if I could take a pill to be perfect, I wouldn't."[13].

Although Winterson dose not appreciate this conduct, the definition of our body actually could be broadened in this way. Here it is implied that the real goal of transgression experiment by Winterson is not merely rebel against traditional social and cultural boundaries, but also lead a dynamic force in cultural production and reproduction. Because we may had regarded society as a reality and discussed "common culture" without caution a quarter of century ago. However, today we cannot consider such holism right after a series of debates without fear of intellectual reprisals. The society itself is moving more and more rapidly, and people should shift with equal acceleration as well. She raises some questions in the novels, which attempt to stimulate readers to challenge whether what we believed in the past still be worthy to trust. Such questions push readers to move out of the comfort zone. Therefore, Winterson attempts to put her faith in the power of thought to change people. She hopes that human should need to change from the inside out, not the outside in.

Second, Winterson argues that human should not just include those owning with organic body. In other word, the definition of human and the definition of body should be questioned, so is the issue of boundary between human and non-human.

In this book, Winterson shows many cases that human should not only include those with organic body. In the story of Planet Blue, the "robot" Spike falls in love with the heroine Billie. In the beginning, Billie rejects to accept this fact and her love. She says, 'I don't want to get personal, but I'll say it again-you are a robot. Do you want to kiss a woman so that you can add it to your database?" [9]. From this case, Winterson starts to refute this thought by what Spike said. “"gender is a human concept,' said Spike, 'and not interesting. I want to kiss you.' She kissed me again.” [9]. Spike's conduct illustrates that all of the conception, definition, as well as the boundary are constructed by society, exactly, human themselves. As the notion of cyborg, human not only includes organic matter, but also inorganic matter. This notion of cyborg proves that human is already a composition of inorganic and organic body. What is more, nowadays these cyborgs are growing more and more sophisticated, such as the new kind like robo-sapiens in the novel. They look like human and are capable of evolution by themselves. In other words, the robot, or cyborg exactly, with artificial intelligence could be called human as well. In this way, Winterson consistently collapses dualistic and binaries thinking particularly related to the human and non-human.

In this part, Winterson attempts to explore the boundary between human and nonhuman. She tries to question whether this traditional boundary still could not be crossed, through which stimulates readers to pay more attention to the cause and the nature of other social boundaries. She hopes that through the experiences of heroin and hero in this book readers could realize that many boundaries in this world could be questioned and challenged. Only people could bravely challenge these boundaries, could the society make a great progress.

Winterson attempts to blur the lines and limits between human body and others, and pushes readers to be discontent with the social and cultural order, rules, norms and traditional shared values. In the meanwhile, Winterson is ambivalent and also remands readers that although the boundaries could be crossed by technology and biology, human should still respect the life and nature in the world. In other words, transgression of the boundary is not the final goal for Winterson's transgression experiment. It is noted by Jenks, "what resides in the word 'transgression' that reaches out, that magnetizes, that touches the shadow sides in us all?" [8]. Therefore, what Winterson really wants is not merely to transgress the boundary between human and non-human, but also push readers to pay closer attention to the issues of boundaries and move out the comfort zone, thinking twice before what we believed and insisted in before.

\subsection{Breaking the Boundary Between Human and Environment}

Human always regard themselves as the holy specie, which is superior that other species. All the time, human always is accustomed to looting resources from nature. However, the environment is not inexhaustive and stable, which is agency that could move by themselves. The purpose of this book is to expect to spark intense debate among readers by blurring the boundary between human and environment.

In the Stone Gods, it is found out a new planet for human to live, because the planet they lived before could only be lived for about fifty years. In that planet, they are lack of fresh air, available resources and so on. "We are running out of planet and we have found a new one" [9]. Because, planet they lived before is polluted by themselves. They thought the resources were abundant at their disposal and the fresh water is rich, then they could always have better quality of life. In fact, when people pollute the nature, and the nature would not be just stable, rather the nature will "fight against" with people. As the nature is an agency, and environment is full of unstable entity. Those unstable entity of the environment and human are the union, which could not separate. Therefore, when the air is polluted, human could not be immune from it.

"There is a red dust storm beginning, like spider-mite, like ants, like things that itch and bite. No one has any idea where the red dust is coming from but it clogs the air-filtering systems, and since it started about two years ago, we are obliged to carry oxygen masks. This one might blow over or it might not." [9].

In this novel, Winterson shows that human could not immune from the pollution of the natural resources. Immersion in pollution and human wastes finally becomes an agency, which could immerse into human in return. As it is noted in this book that "we made ourselves rich polluting the 
rest of the world, and now the rest of the world is polluting us." [9]. It shows that human thought the nature and resources were static and inexhaustible. Actually, the fact is that all matters and every entity in the world are in motion. Therefore, the red dust, as the representation of environment, blurs the line and even transgresses the boundaries between the human and nonhuman. The transgression experiment implies that the destructive human conduct will eventually erase the commonsensical boundaries between human and environment. As the material feminism noted, "The dance of agency between human and nonhuman agents also happens at a more intimate level. The boundaries between our flesh and the flesh of the world we are of and in is porous." [14]

In addition, Winterson still wants to arise readers to think deeply by the challenges in this society, and attracts closer attention to the technology abused. In her interview, she had said that

"I wanted to look at how technology is taking over science, how mechanistic it is. Without wishing to be too polemical, I wanted to challenge people's ideas about what science can do. It's not the solution for everything. I'm quite nervous about technology. Some of it has made our lives infinitely better, but humans are really bad at using things wisely. Every good thing that we make we manage to turn into a negative, which increasingly threatens both the planet and its species. So my question is this: with all these things that we could do, what would we actually do with a new planet?" [13].

Here, she would like to point out the destruction of technology abuse. Human always feel pride of their advanced technology. Actually, technology could not fix anything and could not deal with all of the aftermath for human being. However, while human become more and more relying on the technology in every aspect of life, one day they may gradually degrade and lose their abilities. When all human activities are transferred into technology, the world may be ruled by them. In other words, when human completely rely on technology to solve all the problems, they are also easily controlled by technology. Therefore, the novel presents a warming from the environment that could be even more destructive than the present through reflecting the dehumanizing effects of mechanization and globalization.

It is obvious that Winterson's novel offers a critical attitude to exploitation of nature and destruction of environment. In addition, her novel is informed by a critical attitude to anthropocentrism, and she had illustrated this fact in her interview that "I come from a mill town, and to me the industrial revolution looked like a collective nervous breakdown. The human impact of these technological shifts is often devastating." [13]. As it is seen, the original optimism and belief in progress of technology and science that is with the characteristic feature of modernity will eventually collapse into resource starvation and the revenge that the nature and technology pay back to human beings.

"Winterson is interested in the possibility - and limits - of transformation." [15] Because, what Winterson really wants to do is to provide a platform for sparking intense debate. She uses her book as a manifesto to remand readers to take technology shifts seriously, and think twice before they do.

\section{Conclusion}

Transgression experiment is important for Winterson's novel, because it leads readers to think twice even about normative rules, social principles by breaking social rules, normality and causes a questioning of what was regard as right. In conclude, Winterson's novel, the Stone Gods, provides a great opportunity for expanding, blurring, exceeding the boundary between human and nonhuman. The transgression experiment by Winterson does not merely aims to break a rule, rebel against normative social and cultural constraints, but rather lead a dynamic trend in cultural production and diverse thought, appalling readers to have dynamic thought about everything. Exactly, it is through the attention of the boundary between human and non-human that enables to create a diverse and dynamic literary world.

\section{Acknowledgements}

This work is supported by the Key Project of "Sino-Foreign Interexchange of the Aesthetic Cultures on Silk Roads" from the National Social Sciences Fund of China [Project No.: 17ZDA272].

\section{References}

[1] Onega, S. (2006). Jeanette Winterson. Manchester: Manchester University Press. p. 3.

[2] Yazgünoğlu, K, Y. (2016). Posthuman "Meta (1) morphoses" in JeanetteWinterson's The Stone Gods. CEcozon. vol. 3.

[3] Stonebrook, S. (2009). 'There was no Us and Them': Environmental Justice and Discursive Struggle in Jeanette Winterson's The Stone Gods (Master's thesis). the University of Kansas.

[4] Weiss, M. (2013). Jeanette Winterson's Stone Gods as Trans-world and Trans-gender Dystopia. The Asian Conference on Cultural Studies 2013 Official Conference Proceedings.

[5] Topsakal, G. (2014). Ecocritical Reflections in Jeanette Winterson's the Stone Gods and Maggie Gee's the Ice People: Redefining the Center in Relation to Margins Through Ecological Thinking. Middle East Technical University.

[6] McCulloch, F.(2012). 'Boundaries. Desire': Philosophical Nomadism in Jeanette Winterson's The Powerbook and The Stone Gods. Cosmopolitanism in Contemporary British Fiction.

[7] Damien Gibson. (2016). From Master (y) Narratives to Matter Narratives: Jeanette Winterson's The Stone Gods. http://www.electronicbookreview.com/thread/endconstruction/ stonegods.

[8] Jenks, C. (2003). Transgression. New York: Taylor \& Francis Group. pp. 2-63. 
[9] Winterson, J. (2007). The Stone Gods. New York: Houghton Mifflin Harcourt. pp. 9-39.

[10] Haraway, D. J. (Ed.). (1985). A Cyborg Manifesto: Science, Technology, and Socialist-feminism in the Late Twentieth Century. In Simians, cyborgs, and women: The reinvention of nature. New York: Routledge.

[11] Barnett, T. (2003) The Cyborg and the Garden: Aspects of Jeanette Winterson's Techno-Curiosity. Celebrating Diversity in Research. Vol. 3. No. 1. p. 43.

[12] Antakyalıoğlu, Z.(2012). Jeanette Winterson's The Stone Gods: A Postmodern Warning. Gaziantep Üniversitesi Sosyal Bilimler Dergisi (http://sbe.gantep.edu.tr). Vol. 3. p. 980.
[13] Else, L \& Harris, E. (2007) Science in Fiction: Interview with novelist Jeanette Winterson. In search of grand theory of me. New Scientist.

[14] Alaimo, S \& Hekman, S. (2008). Material Feminism. Bloomington: Indiana University Press. p. 198.

[15] AN Devers. (2019) . "Weird science: Jeanette Winterson talks writing, teaching and queer visions of the future". https://www.prospectmagazine.co.uk/magazine/jeanette-winte rson-profile-frankisstein. 